\title{
THE VALUE RELEVANCE FOR INTERNET OF THINGS ANNOUNCEMENT: EMPIRICAL EVIDENCE FROM THE STOCK MARKET
}

\author{
I-CHENG CHANG, YU- HSUAN YEH \\ Department of Accounting, National Dong Hwa University, Hualien, Taiwan, R.O.C, \\ icc@gms.ndhu.edu.tw
}

\begin{abstract}
With the advancement of science and technology, online applications have emerged in an endless stream. Once everything can communicate and interact with each other through network, the world of the Internet of Things will come into being. This study explore the market reaction and its influencing factors when enterprises announce the launching of new IoT-related products or services, aiming to understand whether investors in the capital market will react to IoT-related announcements and whether such reaction subsequently generates abnormal returns on stock prices.
\end{abstract}

Keywords. Internet of Things, stock market price, capital market

\section{INTRODUCTION}

The information revolution and the development of the Internet have brought the global economy prosperity over the past decade. With the advancement of science and technology, online applications have emerged in an endless stream. Once everything can communicate and interact with each other through network, the world of the Internet of Things will come into being. This is why the Internet of Things (IoT) is regarded as an innovative extension of the Internet. [29] mentioned that the cost for the installation, management and maintenance of IoT is very high, so enterprises need to prove its great value to justify their investment. Otherwise it is not easy to convince investors or creditors into this new sector. Therefore, enterprise managers have great interests in knowing how much the company benefits from IoT and its related products and technologies, and whether it is worthwhile to develop IoT commodities. Besides, the point of view of investors on IoT products or technologies launched by enterprises is also of great interest to management personnel.

According to the Efficient Market Hypothesis, investors react immediately to the information they receive in financial market. Previous literature used to discuss the impact of information technology (IT) on the business value and performance of enterprises ([4]; [8]; [11]; [12]; [16]; [18]; [23]; [28]; [30]; [31]; [32]). The introduction of information systems is a kind of financial investment, so investors will expect the increasing expenditure to be temporary without affecting the company's future cash flow. However, if the market provides additional information, such as the significant improvement of business performance brought about by this information system, such non-financial information will draw investors' attention to its impact on future cash flows (FASB, 1996). [22] pointed out that non-financial and forward-looking information will affect the financial statement model, while forward-looking information includes longterm management strategies (such as information system investment) that may be a potential influencing factor for the company's cash flow. [1] also argue that the accounting research deems the introduction of information system as a strategic orientation, and such non-financial information is related to the market value of enterprise.

As the electronics industry has entered a nearly saturated market with its growth having slowed down, enterprises find it necessary to develop IoT-related products or services to grab new market. The research of [21] shows that when companies announce that their technology is capable of innovation, the capital market will respond with positive abnormal returns (AR) on stock prices; if companies only announce that they "expect" to launch new products, no special reaction will be received from investors. Capital market will not react to a corporate announcement until there is hard evidence for launching new product. [9] also pointed out that for suppliers, announcements of launching new products will generate abnormal returns on stock prices in the capital market. Therefore, this study proceeds from the 
perspective of suppliers to explore the market reaction and its influencing factors when enterprises announce the launching of new IoT-related products or services, aiming to understand whether investors in the capital market will react to IoT-related announcements and whether such reaction subsequently generates abnormal returns on stock prices.

\section{LITERATURE REVIEW AND HYPOTHESIS ESTABLISHMENT}

The term "Internet of Things" was proposed by Kevin Ashton at the Auto-ID Center of Massachusetts Institute of Technology in 1999. This term means that objects are connected to the Internet through Radio Frequency Identification (RFID) [33]. At present, the definition of the concept of IoT varies from industry, government to academia. In 2005, the International Telecommunication Union (ITU) officially released the concept of the Internet of Things (IoT), indicating the advent of an era featuring "ubiquitous" IoT communication, in which everything in the world can actively exchange information through the Internet so that anybody and anything can be connected at any time and anywhere ([17], [24]). According to [34], the Internet of Things is the protocol-based exchange and communication of information enabled by devices connected through the Internet, such as radio frequency identification technology (RFID), infrared sensor (IR) and global positioning system (GPS), to realize intelligent identification, location, tracking, monitoring and management.

When information technology has become the backbone of business and the basis of corporate operation, we need to understand the impact of information technology investment on enterprise value. Scholars have begun to study the response of capital market to enterprise investment in information technology ([12]; [15]; [16]; [31]). [12] and [31] have found that information technology investment is associated with market return. The empirical study of 367 enterprises by [6] shows that the investment in information systems can make a significant contribution to enterprise value. Following their research scholars have successively explored the reaction of investors to different information technology issues. [16] used the event study method to explore the market reaction to the corporate announcement of introducing ERP system, in which he found that the first time of announcement will receive positive significant response from the market. [35] also used the event study method to investigate the cumulative abnormal return rate of 251 companies announcing the implementation of e-commerce, the results of which showed that the market presented a significant positive response.

This study considers IoT one of the links of information technology. Enterprises actively develop IoT-related products or services in the hope of effectively transforming their business into a high valueadded industry and generating a positive effect on the future cash flow by introducing new products or services. When investors can effectively access the information, they may change their previous expectations of the company's cash flow and give new evaluation of the real enterprise value, which is reflected by the stock price and consequently generates positive abnormal returns. Therefore, this study anticipates that the stock price will react positively when companies announce the launch of IoT-related products or technologies and investors will earn abnormal returns on the stock price. Given such anticipation, this paper establishes a hypothesis as follows:

H1: When enterprises announce the launch of IoT-related products or technologies, the capital market will generate positive abnormal returns on stock prices

Studies have pointed out that different company characteristics, such as company size, financial status and industry, may contribute to clarifying the intensity and direction of market reaction ([2]; [13]; [14]; [15]; [16]). Both [5] and [19] indicate that the market reaction to information technology investment will be affected by company size. This study considers that small-size companies, despite their limited budget, is still able to develop and launch new products or services in line with market trends because they expect the new products to exert a positive effect on the future corporate cash flow. When investors have effective access to such information, they may therefore change their previous expectations of the company cash flow and give new evaluation of the real enterprise value, which is reflected by the stock price and consequently generates positive abnormal returns. Therefore, this study considers that the announcement of launching new IoT-related products or technologies by small-size companies will lead the capital market to react considerably. As a result, investors earn abnormal returns on stock prices. Given such anticipation, this paper establishes a hypothesis as follows: 
H2: Compared with large companies, the announcement of launching new IoT-related products or technologies by small-size companies will lead to higher abnormal returns on stock price

Merely considering the enormous business opportunities in the IoT market, many enterprises start to chart new territory despite the high threshold. However, the fierce competition and a saturated market make it difficult for new products to achieve popularity in the consumer market. More efforts are needed in areas such as marketing and after-sales services ([27]). [27] also indicate that the more complicated product design, sophisticated built-in technology and multi-layer new information architecture explain the rising fixed cost of IoT products, posing huge obstacles for new companies in the IoT market. This study considers that as global procurement intensifies and more developers emerge to fuel the fierce competition, the time and cost that IoT suppliers invest in developing a new product, including the remuneration to recruit new technology talents and the extra effort to launch products, will inevitably result in higher demand for capital and resources. If a company is financially sound, it will have sufficient resources to bear huge expenditure, so the financial burden is relatively small and the risk of bankruptcy is also relatively low. Therefore, this study considers that when a financially sound company endeavors to promote the company's future cash flow by introducing new technology and products, the capital market will react considerably to its announcement and investors will earn abnormal returns on stock prices. Given such anticipation, this paper establishes a hypothesis as follows:

H3: The announcement of launching new IoT-related products or technologies by a financially sound company will lead to higher abnormal returns on stock price

\section{RESEARCH METHOD}

\subsection{Research Data and Process}

This study takes listed companies and OTC companies in Taiwan as samples. From 2012 to 2016, we used newspaper electronic database (joint knowledge base) to input keywords such as "Internet of Things", "Internet of Vehicles" and "IOT" to select samples. We also select the date of reporting the news of enterprises' launching IoT products or services as the event date. After unrelated reports and information regarding non-listed or non-OTC companies are excluded, 491 samples were obtained, the selection process of which is shown in Table 1 . The daily stock prices and related financial information of the sample companies were obtained from the Taiwan Economic Journal Database (TEJ).

\subsection{Definition of Research Variables}

1) Dependent variable

Cumulative Average Abnormal Returns (CAR): The CAR of all sampled companies during the event.

2) Independent variables

The financial data of this study are taken from the annual financial reports of the sampled companies on the date of the event:

1. Size: In order to avoid excessive differences in total assets, the total assets of sampled companies are measured by natural logarithm ([7]; [10]).

2. Financial soundness (Z-score): This study adopts the Altman's Z-score values used in previous studies of [3], [25]; 26]).

3) Control variables

1. Time: Virtual variable. If the announcement date of the sampled event is between 2015 and 2016, it is 1 , otherwise it is 0 .

2. Return on Sales (ROS): Net after-tax profit divided by net sales.

3. Operating Profit Ratio (OPR): Net operating profit divided by net sales.

4. Total Assets Turnover (TAT): Net sales divided by average assets.

5. Industry: Virtual Variable. Industry1 indicates that a sampled company engaged in the computer and peripheral equipment industry or communication network industry will be marked as 1 , otherwise it will be 0 ; Industry 2 indicates that a sampled company engaged in the industries of semiconductor, 
optoelectronic, electronic components, electronic access and information service will be marked as 1 , otherwise it will be 0 .

Table 1 Analysis on Source of Sampled Companies

\begin{tabular}{|c|c|c|c|}
\hline Step & Sample Collection Process & $\begin{array}{c}\text { Number of } \\
\text { Sample }\end{array}$ & Total \\
\hline Step 1 & Input Keywords & & 8,465 \\
\hline Step 2 & Exclusions: & & \\
\hline \multirow{5}{*}{ Step 3} & - Non-IoT Event Announcement & $(7,846)$ & \\
\hline & - Non-listed or non-OTC companies & $(128)$ & $(7,974)$ \\
\hline & Exclusions: & & \\
\hline & - Samples of financial industry & (8) & \\
\hline & $\begin{array}{l}\text { - Announcement atfected by other events (e.g. dividend } \\
\text { payments, earnings announcements, mergers, litigation and } \\
\text { strikes) }\end{array}$ & $(32)$ & \\
\hline \multirow{3}{*}{ Step 4} & - Repeated publication & $(112)$ & $(152)$ \\
\hline & Minus: financial information missing & & $(7)$ \\
\hline & H1 All samples & & 332 \\
\hline \multirow[t]{3}{*}{ Step 5} & Minus: missing control variable (financial data) & & (1) \\
\hline & Minus: Extreme values of variables & & (19) \\
\hline & H2 H4 All samples & & 312 \\
\hline
\end{tabular}

\section{EMPIRICAL RESULTS AND ANALYSIS}

\subsection{Descriptive analysis}

Table 2 is the descriptive statistics of market reaction and its influencing factors of the announcement released by sampled on the launch of IoT products or technologies. Table 2 shows that the cumulative average abnormal return (CAR) representing market reaction is positive (1.014), which shows that the market reaction to corporate announcement tends to be greater than 0 . Generally the average total assets of sampled companies taken after natural logarithm (size) is 17.246; the average Z-score is 4.024, which is more than 2.99 , indicating that the financial status of the whole sample is sound.

Table 2 Descriptive Statistics

\begin{tabular}{lcccc}
\hline Variables & Minimum & Maximum & Average mean & $\begin{array}{c}\text { Standard } \\
\text { deviation }\end{array}$ \\
\hline H2 H4 All samples (N= 312) & & & & 4.924 \\
CAR (-3, +3) & -16.064 & 16.045 & 1.014 & 2.007 \\
Size & 12.879 & 21.676 & 17.246 & 3.029 \\
Z-score & -1.478 & 27.885 & 4.024 & 0.448 \\
Time & 0 & 1 & 0.720 & 10.005 \\
ROS & -51.600 & 36.340 & 5.796 & 8.957 \\
OPR & -31.740 & 39.870 & 6.719 & 0.471 \\
TAT & 0.070 & 2.800 & 1.024 & 0.500 \\
Industry $_{\boldsymbol{1}}$ & 0 & 1 & 0.470 & 0.487 \\
Industry $_{2}$ & 0 & 1 & 0.380 & \\
\hline
\end{tabular}

\subsection{Empirical results}

In addition, this study carries out a single sample $\mathrm{T}$ test for the cumulative average abnormal returns (CAR). Table 3 shows that during the period when the Internet of Things events are announced, the average number is greater than 0 , and the $P$ value is 0.000 , which indicates the level of confidence of 99\%. This shows that at the significant level of $1 \%$, the sampled companies in this study have a significant cumulative average abnormal return (CAR) over 0 in each period, indicating that the announcement of IoT events will generate positive abnormal returns on stock prices. 

EMPIRICAL EVIDENCE FROM THE STOCK MARKET

Table 3 Single Sample T Verification of Cumulative Average Abnormal Returns (CAR)

\begin{tabular}{|c|c|c|c|c|c|}
\hline \multirow[b]{2}{*}{ Event Date } & \multicolumn{5}{|c|}{ Verified value $=0$} \\
\hline & $\operatorname{CAR}(-3,+3)$ & $\operatorname{CAR}(-2,+2)$ & $\operatorname{CAR}(-1,+1)$ & $\operatorname{CAR}(0,+1)$ & $\operatorname{CAR}(-1,0)$ \\
\hline $\mathbf{t}$ & 4.185 & 4.539 & 5.447 & 5.262 & 4.377 \\
\hline Freedom & 331 & 331 & 331 & 331 & 331 \\
\hline Significance $^{a}$ & $0.000 * * *$ & $0.000 * * *$ & $0.000 * * *$ & $0.000 * * *$ & $0.000 * * *$ \\
\hline Average & 1.334 & 1.330 & 1.224 & 0.984 & 0.867 \\
\hline
\end{tabular}

${ }^{a}$ Significant level of double tails.

Note: $* * *, * *$ and $*$ represent significant levels of $1 \%, 5 \%$ and $10 \%$ respectively.

(1) Influencing factors of market reaction to announcements

Given the fact that corporate announcements of IoT events will generate abnormal returns on stock prices, this study will continue to explore the influencing factors of the cumulative average abnormal returns. Through linear regression of the least square method, we can capture the systematic part of random variables and observe the correlation between independent variables and control variables and the changes of CAR $(-3,+3)$ to see whether the hypothesis is supported by statistical evidence. The results are summarized in Table 4.

Table 4 Regression Analysis Results -- CAR(-3, +3)

$$
C A R_{(-3,+3)}=\alpha_{0}+\alpha_{1} \text { Size }+\alpha_{2} Z-\text { score }+\alpha_{3} \text { Time }+\alpha_{4} R O S+\alpha_{5} O P R+\alpha_{6} \text { TAT }+\alpha_{7} \text { Industry }+\alpha_{8} \text { Industry }+\varepsilon
$$

\begin{tabular}{|c|c|c|c|c|c|c|}
\hline \multirow{2}{*}{ Variable } & \multirow{2}{*}{$\begin{array}{l}\text { Predicted } \\
\text { Direction }\end{array}$} & \multirow{2}{*}{ Coefficient } & \multirow{2}{*}{$\mathbf{t}$} & \multirow{2}{*}{ Significance $^{a}$} & \multicolumn{2}{|c|}{ Collinear Statistics } \\
\hline & & & & & Tolerance & VIF \\
\hline Intercept & & 6.663 & 2.423 & .016 & & \\
\hline Size & -- & -.293 & $1 . \overline{9} 78$ & $.049 * *$ & .871 & 1.148 \\
\hline Z-score & + & .023 & 209 & .834 & 682 & 1.465 \\
\hline Time & + & -.032 & -.051 & .959 & .963 & 1.038 \\
\hline ROS & & .057 & 1.043 & .298 & .262 & 3.817 \\
\hline$O P R$ & & -.103 & 1.590 & .113 & .230 & 4.355 \\
\hline$T A T$ & & -1.284 & $1 . \overline{9} 46$ & $.053^{*}$ & .796 & 1.256 \\
\hline Industry $_{1}$ & & 1.273 & 1.380 & .168 & .362 & 2.761 \\
\hline Industry $_{2}$ & & 1.066 & 1.179 & 239 & 396 & 2.523 \\
\hline
\end{tabular}

Dependent variable: CAR $(-3,+3)$

${ }^{a}$ Significant level of double tails.

Note: $* * *, * *$ and $*$ represent significant levels of $1 \%, 5 \%$ and $10 \%$ respectively.

\section{CONCLUSION AND SUGGESTIONS}

This study takes listed and over-the-counter companies that announced Internet of Things-related products or services between 2012 and 2016 as samples, and uses event research method to explore whether abnormal returns on the stock prices of companies will be generated when such announcement occurs. According to the study, when enterprises announce IoT-related products or technologies, the capital market will generate positive abnormal returns. This result is in line with the results obtained in the previous introduction of information technology ([16]; [20]; [30]; [35]). The change of CAR is the most significant on the announcement date, the day before and the next day, showing that investors regard this announcement as good news for the future benefits of the company. In addition, the size and financial soundness of the company also affect the cumulative average abnormal returns. The regression results show that small-size firms generate more intense reaction to abnormal stock price than large firms, which is consistent with the research of [15] and [30]; financially sound companies register higher abnormal 
returns on stock prices without reaching a significant level, which is consistent with the research of [16]. The regression results of time (virtual variable) is the opposite to the predicted direction without reaching a significant level, indicating that the CAR $(-3,+3)$ at the moment of the announcement of the sampled companies is not affected by the year of announcement. The reason may be that as the electronics industry has entered a nearly saturated market with its growth having slowed down, enterprises that intend to seek new markets by developing IoT-related products or services will receive the positive reaction of the capital market. Nevertheless, as the future environment changes and new challenges occur, the corporate transformation is an irresistible trend for the capital market. In this context, pursuing progress and innovation remains the only alternative for the survival of enterprises.

\section{REFERENCES}

[1] Amir, E. and B. Lev. 1996. Value-relevance of nonfinancial information: the wireless communications industry. Journal of Accounting and Economics 22 (1-3):3-30.

[2] Atiase, R. K. 1985. Predisclosure information, firm, capitalization and security price behavior around earnings announcements. Journal of Accounting Research 23 (1): 21-36.

[3] Barron, O. E., C. O. Kile and T. B. O'Keefe. 1999. MD\&A quality as measured by the SEC and analysts' earnings forecasts. Contemporary Accounting Research 16 (1): 75-109.

[4] Benco, D. C. and L. Prather. 2008. Market reaction to announcements to invest in ERP systems. Quarterly Journal of Finance \& Accounting 47 (4): 145-169.

[5] Brynjolfsson, E. 1994. Information assets, technology and organization. Management Science 40 (12): 16451662.

[6] Brynjolfsson, E. and L. Hitt. 1996. Paradox lost? Firm-level evidence on the returns to information systems spending. Management Science 42 (4): 541-558.

[7] Byoun, S. 2008. How and when do firms adjust their capital structures toward targets? The Journal of Finance 63 (6): 3069-3096.

[8] Chari, M. D. R., S. Devaraj and P. David. 2008. The impact of information technology investments and diversification strategies on firm performance. Management Science 54 (1): 224-234.

[9] Chen, S. S., K. W. Ho, K. H. Ik and C. F. Lee. 2002. How does strategic competition affect firm values? A study of new product announcements. Financial Management 31 (2): 67-84.

[10] Chen, S. S. 2006. The economic impact of corporate capital expenditures: Focused firms versus diversified firms. Journal of Financial and Quantitative Analysis 41 (2): 341-355.

[11] Dewan, S. and F. Ren. 2009. Information technology and firm boundaries: impact on firm risk and return performance. Information Systems Research 22 (2): 369-388.

[12] Dos Santos, B. L., K. Peffers and D. C. Mauer. 1993. The impact of information technology investment announcements on the market value of the firm. Information Systems Research 4 (1):1-23.

[13] Feroz, E. H. and E. R. Wilson. 1992. Market segmentation and the association between municipal financial disclosure and net interest costs. The Accounting Review 67 (3): 480-495.

[14] Grant, E. B. 1980. Market implications of differential amounts of interim information. Journal of Accounting Research 18 (1): 255-268. 
[15] Hayes, D. C., J. E. Hunton and J. L. Reck. 2000. Information systems outsourcing announcements: Investigating the impact on the market value of contract-granting firms. Journal of Information Systems 14 (2): 109-125.

[16] Hayes, D. C., J. E. Hunton and J. L. Reck. 2001. Market reaction to ERP implementation announcements. Journal of Information Systems 15 (1): 3-18.

[17] He, M., C. Ren, Q. Wang, B. Shao and J. Dong. 2010. The Internet of Things as an enabler to supply chain innovation. IEEE 7th International Conference on E-Business Engineering: 326-331.

[18] Huang, C. K., T. Wang and Y. T. Tsai. 2016. Market reactions to big data implementation announcements. 20th Pacific Asia conference on Information systems (PACIS) 2016 Proceedings.

[19] Im, K. S., K. E. Dow and V. Grover. 2001. Research report: a reexamination of IT investment and the market value of the firm -- an event study methodology. Information Systems Research 12 (1): 103-117.

[20] Jeong, B. K. and A. C. Stylianou. 2010. Market reaction to application service provider (ASP) adoption: An empirical investigation. Information \& Management 47 (3): 176-187.

[21] Kelm, K. M., V. K. Narayanan and G. E. Pinches. 1995. Shareholder value creation during R\&D innovation and commercialization stages. Academy of Management Journal 38 (3): 770-786.

[22] Lang, M. H. and T. D. Warfield. 1997. Response to the FASB invitation to comment, "Recommendations of the AICPA special committee on financial reporting and the association for investment management and research. Accounting Horizons 11 (1): 139-156.

[23] Lim, J. H., B. Dehning, J. V. Richardson and R. E. Smith. 2011. A meta-analysis of the effects of IT investment on firm financial performance. Journal of Information Systems 25 (2):145-169.

[24] Lin, M. and J. G. Zhang. 2011. The application and development of Internet of Things with its solutions of restrictive factors. International Conference on Mechatronic Science, Electric Engineering and Computer (MEC): 282-285.

[25] Miller, G. S. and D. J. Skinner. 1998. Determinants of the valuation allowance for deferred tax assets under SFAS No. 109. The Accounting Review 73 (2): 213-233.

[26] Newberry, K. J. and D. S. Dhaliwal. 1998. The effect of taxes on U.S. multinationals' source of foreign debt decisions. University of Arizona.

[27] Porter, M. E. and J. E. Heppelmann. 2014. How smart, connected products are transforming competition. Harvard Business Review. https://hbr.org/2014/11/how-smart-connected-products-are-transformingcompetition.

[28] Prasad, A. and J. Heales. 2010. On IT and business value in developing countries: a complementaries-based approach. International Journal of Accounting Information Systems 11 (4): 314-335.

[29] Silva, E. M. and P. Maló. 2014. IoT testbed business model. Advances in Internet of Things 4: 37-45.

[30] Son, I., D. Lee, J. N. Lee and Y. B. Chang. 2014. Market perception on cloud computing initiatives in organizations: An extended resource-based view. Information \& Management 51 (6): 653-669

[31] Tam, K. Y. 1998. The impact of information technology investments on firm performance and evaluation: evidence from newly industrialized economies. Information Systems Research 9 (1): 85-98. 
[32] Wang, L., K. L. Gwebu, J. Wang and D. X. Zhu. 2008. The aftermath of information technology outsourcing: an empirical study of firm performance following outsourcing decisions. Journal of Information Systems 22 (1): $125-159$.

[33] Wu, M., T. J. Lu, F. Y. Ling, J. Sun and H. Y. Du. 2010. Research on the architecture of Internet of Things. 2010 3rd International Conference on Advanced Computer Theory and Engineering (ICACTE): V5484-V5-487.

[34] Yu, C. 2011. Research and design of logistics management system based on Internet of Things. 2011 2nd International Conference on Artificial Intelligence, Management Science and Electronic Commerce (AIMSEC): 6314-6317.

[35] Subramani, M., \& Walden, E. (2001). The impact of e-commerce announcements on the market value of firms. Information Systems Research, 12(2), 135-154.

Received on February 1st, 2019

Accepted on March 25th, 2019 